\title{
Ficções de Heloisa Pires Ferreira
}

\author{
Leon Kossovitch ${ }^{1}$
}

Mayra Laudanna ${ }^{2}$

\section{Resumo}

Apresenta-se aqui, a obra e a linguagem de Heloisa Pires Ferreira a partir de suas gravuras e tecidos, assim como de diversas entrevistas concedidas pela artista.

\section{Palavras-chave}

Artes, Estética, Gravura, Bordado, Linguagem.

1 Professor Doutor do Departamento de Estética da Faculdade de Filosofia, Letras e Ciências Humanas da Universidade de São Paulo (FFLCH-USP). São Paulo, Brasil.

2 Professora Doutora da Área de Artes do Instituto de Estudos Brasileiros da Universidade de SãoPaulo ( IEB - USP). São Paulo, Brasil. E-mail: mayra@usp.br 


\section{Fictions d'Heloisa Pires Ferreira}

Leon Kossovitch

Mayra Laudanna

\section{Résumé}

Il s`agit ici de la présentation de l'oeuvre et du langage de Heloisa Pires Ferreira à partir de ses gravures et des ses étoffes, aussi bien que de plusieurs entretiens tenus par l'artiste avec des différents interlocuteurs.

Most-clefs

Arts, Esthétique, Gravure, Broderie, Langage 


\section{Heloisa Pires Ferreira's Fictions}

Leon Kossovitch

Mayra Laudanna

\section{Abstract}

This article presents Heloisa Pires Ferreira's work and language through an appraisal of her engravings and fabrics, as well as from many interviews given by the artist.

Keywords

Art, Esthetic, Engraving, Embroidery, Language. 
(nila Heloisa Pires Ferreira na fala, que, fonte, fá-la nascer: mais que instrumento que cubra o silêncio no qual a artista se teve por muito tempo aprisionada, a fala é o solo de que brotam os atos que a declaram liberta. Fabulação de evento, a fala incide em duas narratividades discursivas que preceituam a arte e a linguagem, às quais desloca quando se ergue como educadora na cura e na libertação (1). Nessa ascensão, a fala faz florescer enunciados ficcionais, que partilham com as proposições técnicas a arte e a linguagem de Heloisa. Também é nesta fabulação que a fala expõe a artista como dispensadora do bem, sem, por isso, retirar da linguagem a função discursiva em que a verossimilhança técnica domina. Não se situando na derivação de uma linguagem única que se estabeleça como primitiva enquanto discurso técnico, a arte de Heloisa tampouco se reduz, com a fala que a envolve, a efeito ou aplicação; quanto à inoperância de hierarquia entre a linguagem e a arte, ambas se explicitam tecnicamente equivalentes, o que as faz espelhar-se, como discursivas, em abismo. Entretanto, como ambas, enquanto discursividades procedimentalmente verossímeis, estão separadas da fala, a fabulação, nesta, é o que as envolve com narrações vindas de outra vertente: miraculadas em seus efeitos, a arte e a linguagem se fazem admirar, pela fala, no gênero do maravilhoso. 


$$
\text { ed }
$$


A linguagem opera como discurso com a arte no abismo dos verossímeis técnicos, espraiando-se entretanto como fala: com esta, a arte se ficcionaliza, de modo que o maravilhoso se estende não só a elas, como também à própria protagonista, exposta no cruzamento da descrição miraculada da política e da terapêutica, cujo princípio prático é a pedagogia da fala emancipada (2); a protagonista, como narradora, é a biografada nas descrições, que lhe traçam um retrato epidítico. Estando excluída toda precedência, a convencional do realismo e do idealismo, ainda hoje normatizadora dos discursos, o entrecruzamento da linguagem e da arte dispensa o raso e o profundo da subjetividade: a autoria, na fala de Heloisa, anda nos enunciados técnicos e nos fabulosos, desandando nos efeitos da enunciação as concatenações discursivas.

O bordado e a gravura distinguem-se na pesquisa artística de Heloisa: os enunciados técnicos que deles tratam se metamorfoseiam na fala em que se libertam da temporalidade do sucessivo, como a especificada pelas periodizações, pois cruzadas por linhas cursivas e recursivas nas quais se singularizam pontos que, expondo inflexões ou rupturas, não anulam, contudo, tendências e constâncias. Sendo impertinente, nessas artes, a suposição de fases no concernente à fala, não há nascimento empírico ou conceitual da obra e da artista na ficção que mostra, fora dos verossímeis discursivos, devires, metamorfoses, contrastes, todos eles alheios a hierarquias e sentidos dados. O paralelismo da ficção na arte e na linguagem, desdenhando a subordinação de uma à outra, solta a fábula, que, valorizando o diálogo na fala, faz entrar e sair personagens da cena epicamente representada. Como as prosopopéias efetuam o épico tanto com falas centradas na artista, quanto com as dos personagens que com ela dialogam, a dramatização pode desenrolar-se diante de cenários, como os de sessões de gravura e bordado, mas também os de aula, assim como os de rua: são hipérboles operadoras de metamorfoses sem localização ou agente prefixados, podendo alegorizar-se personificações, como as obras, repentinamente falantes.

Não se hierarquizando, na fala, a linguagem e a arte, propõem-se os gêneros epidítico e deliberativo, associáveis à terapêutica e à política; por eles, a fala é evidenciada encenadora dramática dos conflitos do Brasil, da América Latina e, em geral, do mundo explorado pela finança. O épico, na fala, que é hipérbole inclusiva, não diferencia a atuação política do retiro reflexivo, de modo que a personagem central, a um tempo testemunha, educadora e doadora, joga com o contraste no qual o maravilhoso é efetuado como quiasma: amplificando os termos, o político pode ser mostrado como contemplação anticonformista e a contemplação, como intervenção deliberativa. Maravilhoso, o quiasma suscita, 
blicar três volumes do livro Gravura brasileira hoje. Eu posso, através da minha fala, também despertar o outro e ele começar a falar das questões dele. ${ }^{1}$

2 Tinha o sofrimento que você via em toda a situação - como é asfixiante, prepotente, alguns poderosos dominando e massacrando o resto. Nessa época, eu era inteiramente massacrada - hoje não sou mais -, era massacrada e o sofrimento era muito maior do que qualquer outra coisa. ${ }^{2}$

Então, ou eu morria ou eu me expressava, mas eu não podia me expressar por palavras, eu comecei a ter consciência de que a minha educação, a nossa educação, era para sermos do silêncio. ${ }^{3}$

É como se eu tivesse crescido. Naquela época, eu tinha um sufoco, e ele era tal que eu não podia nem falar. Nós saíamos de uma ditadura e na ditadura nós não falávamos mesmo: eu tinha que aprender a falar. Não sabia falar ainda e, ao mesmo tempo, tinha que falar, porque tinha que falar. ${ }^{4}$

É como a criança, ela murmura, ela faz 'uoem', você pensa que ela está chorando, mas não, ela está aprendendo a falar. ${ }^{5}$

3 Nós éramos da cultura do silêncio, então eu não podia... Naquela ocasião, eu jamais falaria com você como eu falo hoje, jamais. [...] Nesse rolo todo, eu fui convidada para montar uma oficina de gravura no Sesc, isso no final de 82, quando eu fazia uma grande exposição na Cândido Mendes.

1 FERREIRA, Heloisa Pires. Entrevista concedida a Mayra Laudanna. Cotia: Ateliê Editorial, 2001. p. 49-50. (Entrevista de Artista).

2 Idem, ibidem. p. 6-7.

3 Entrevista concedida por Heloisa Pires Ferreira a Mayra Laudanna. Rio de Janeiro, 2000, sem edição. Editada e revista pela artista, a entrevista foi publicada pela Ateliê Editorial, em 2001.

4 FERREIRA, Heloisa Pires. Entrevista concedida a Mayra Laudanna. Cotia: Ateliê Editorial, 2001. p. 6. (Entrevista de Artista).

5 Ver nota 3. 
no cotejo, paixões extremas, em que a arte e a linguagem, por um lado, e a contemplação e o empenho, por outro, se expõem como a epopéia de duas navegações cruzadas, da que singra o mundo, limpando-o da imundície, da que mergulha na biografada, corrigindo, ela também mundo, aquele imundo.

O paralelismo das duas descrições ficcionais na relação das duas direções épicas não impede que, além dos percursos traçados pelos temas, exponham-se os périplos das insistências em que os significados deslizam, ora amarfanhados, ora escapados, ora cobertos. O épico encena, na fala, a própria artista seguindo tais périplos, não só como testemunha central dos eventos narrados, distinta, como sujeito do enunciado, das mais personagens que evoluam cá e lá como protagonistas ocasionais em cenários a eles adequados, o morro, a escola, a oficina, o lar, todos eles intercambiáveis em ação alheia a precedências, mas também como sujeito da enunciação, com suas rasuras e mais apagamentos. Considerados esses dois sujeitos da linguagem (3), a fala de Heloisa sobre a gravura não antecipa os temas aos procedimentos, nem, inversamente, as articulações gráficas e discursivas aos significados épicos ou outros, pois tudo gira, não só deliberativa e epiditicamente, como também imprescrita e bizarramente. Os saltos, furos, vacilações, reforçam, no que concerne à epopéia de Heloisa, os efeitos maravilhosos de devires e metamorfoses, operantes tanto na significação associada às ambigüidades e contradições dos temas, quanto, ressalte-se, na articulação ligada às heterogeneidades e sobreposições das técnicas e mais procedimentos nos bordados em tecidos e nas gravuras em papéis que as oscilações na enunciação repropõem.

A epopéia, por narrar na linguagem e na arte em seqüências de enunciações e gestos, respectivamente, é distinguida por escansões, as quais, diferenciando, não raro descontinuam, com os deslizamentos da fala, os significados, que se amarfanham, se recobrem, se desprendem. As duas epopéias, que à narradora incluem, são ou costuradas por justaposições de pedaços ou interrelacionadas por partes de composições transicionais. O maravilhoso na ficção de Heloisa é, assim, o resultado da conjunção das duas epopéias, muita vez indiscerníveis na fala que a ambas abrange, mas também é o produto do devir em que, seja por efeito de proximidade, pela qual os pedaços se afetam sem se interceptar e sem se modificar, seja por efeito de passagem, pela qual a metamorfose, por intersecção, a todos modifica. O maravilhoso salta, assim, da conjunção de seres contrastados e seus devires, evidenciados em sua presença recíproca; é nos devires que se declaram as metamorfoses e nas metamorfoses, os devires, modificando-se os termos da linguagem e 
Eu tinha que ir estudar, foi um dos motivos de eu falar para a pessoa do Sesc que eu não estava interessada. Eu não podia ficar presa lá, dando aulas, ensinando gravura, nada disso não, porque ou eu morria ou eu ia para os lugares. Mas eu não disse isso para ninguém, primeiro porque eu não tinha como dizer, porque eu não falava [...], então, como dizer: "eu tenho que ir para a Embaixada do Chile".

Mas eu não tinha pressa, então não tinha problema, e fiz uma série de pastéis, uma série de aquarelas, fiz uma grande exposição na Cândido Mendes, e me convidaram para essa coisa da gravura lá no Sesc. [...] A vida te traz essas coisas nas fuças, você tem que deixar... tem que ir. Porque ela te traz isso, porque era aquela hora. ${ }^{6}$

E eu, quando eu ficava perdida [...], eu desenhava, desenhava, desenhava e, ao mesmo tempo, [...] com eles, eu dava aulas desde criança [...] na favela, não era bem na favela, era dentro de uma escola pública, aos domingos, e os favelados todos iam para lá. O Osmar não freqüentava, ele não curtia essa coisa de ficar dando aulas para os pobrinhos, ele não curtia, mas ele ia às reuniões, que começavam às oito horas da noite e acabavam à uma da manhã, em que se ficava analisando todos os cursos que a gente tinha dado no dia. Isso aos domingos, que começavam a uma da tarde e acabavam às sete da noite, passava filme, eu era assim um speed boy, pau prá toda obra: eu ia buscar filme, [...] eu preparava as tintas, cortava os papéis. ${ }^{7}$

Era a primeira a chegar, porque adorava aquilo, e ficava o dia inteiro. Eles me contaram, agora, que tinham a maior dificuldade em se relacionar com aqueles meninos - uns já eram homens, eu tinha uns quinze anos e havia garotos de dezoito, mulheres de dezoito, porque no morro são mulheres, e com filhos. Eu tinha que aprender tudo com a Maria Lúcia, o Rogério, porque eu era uma debilóide completa. E eles me contaram que ficavam de olho naquilo que eu fazia, porque eu conseguia me comunicar com aquelas pessoas com muita facilidade. Isso eu não conseguia com eles, mas quando estava com essas pessoas, eu era completamente diferente: tinha

6 Ver nota 3.

7 Ver nota 3. 
da arte: modos, os termos ou se imantam ou entre si transitam, a ambas determinando. Na presença de termos a termos, há efeitos de contraste, definindo-se, por este, os devires e as metamorfoses que têm a polaridade por referência. Eclodindo o maravilhoso tanto nos contrastes quanto nas metamorfoses e devires, neles se abre a vasta floração das modificações. São devires, em que os termos metamórficos não requerem a homogeneidade de um conjunto, pois podem ser atribuídos a séries heterogêneas, assim, nas gravuras de mapa e animal, que apenas pela evidência política constituem série. Aderida à linguagem e à arte, a fala fabula, pondo-se a deliberar e a demonstrar às expensas dos verossímeis do discurso técnico, no que as descontinuidades da enunciação não colidem com a ficção, antes a ampliam, sendo seus efeitos multiplicados por não se as poder incluir em qualquer gênero porque produzidas como heteróclito, evidentemente imprescrito e inverossímil.

Como nas metamorfoses e nos devires, nos contrastes, de que as conjunções são espécies, brotam maravilhas: aproximados, Karl Marx e Rudolf Steiner, mas, não menos, o ensino dado na sobrevivência de favelados do Rio de Janeiro e o oferecido na vivência de escola antroposófica de São Paulo, luzem no cotejo de Heloisa (4). Esses pares de termos, que podem ser considerados excludentes como incompatíveis quando politicamente relacionados, uma vez postos em presença, operam maravilha, dramatizando a fala; em tal bizarria, tanto a política quanto a terapêutica surgem, admiráveis, pois, suspendendo a mirada, soltam-se dos verossímeis discursivos: no cotejo dos termos polares, o que fascina é a fala, em detrimento do discurso que os tem como politicamente excludentes. Do verossímil, o discurso da política, da terapêutica e da educação, que a ambas sustém, encanta na fala envolta de admiração; sendo contidos os argumentos do discurso, maravilhadora, a fala opera com junções extravagantes, que, inverossímeis, desdenham o gênero humilde da análise, diluída pelas alturas dos entimemas dramatizadores.

Encantatória, a fala joga com contrastes, não com contradições, que só no discurso se produzem entre termos, pois a educação de Heloisa envolve a política, lançando-a no imprescrito da contemplação empenhada e da intervenção extática, principalmente no extremo da dor, registrada na baixeza da ditadura militar, atro teatro de seu silêncio. Embora dois silêncios se assinalem na artista, o que, indeterminado, a persegue desde a infância, e o que se define como político pois exposto pela ditadura brasileira, é este que põe em evidência a educação, portanto a fala, contrastadas com a mudez e a dor, que assinala a saída de Heloisa do ensino em escola de favela, sua chegada ao que chama "individualismo", no qual o trabalho artístico a mantém calada, e sua ascese à instituição steineriana 
uma paciência muito grande, um carinho muito grande e ensinava tudo, tudo e catalisava a capacidade criadora deles. ${ }^{8}$

Como eu mexia com as pessoas das favelas, com as pessoas pobres, pensei em fazer serviço social, só que, quando entrei na Faculdade, vi que não era nada disso, absolutamente. Aquelas pessoas me diziam coisas que não tinham nada a ver com aquela realidade que eu tinha vivido durante dois anos, então, não era aquilo que eu queria. Eu fui pegar na Faculdade os meus papéis de volta... [...] Então pensei: "tenho que estudar as escolas" e lá fui eu estudar as escolas para ver se era aquilo que eu queria. Tinha uma escola Waldorf aqui no Rio, pequenininha; fui lá conversar com a moça e ela me disse: "olha, nós estamos fechando, mas tem uma grande escola em São Paulo e lá você pode estudar, você pode tudo”. Aí fui a São Paulo e, já que eu não podia falar, escrevi tudo o que achava de educação, o que pensava que era e fui. Conversei com eles e acho que gostaram muito de mim, porque me quiseram na hora. Aceitaramme como professora auxiliar, no jardim da infância [...].

Na Rudolf Steiner [Waldorf] foi um ano muito bom: tive aula de filosofia, da filosofia deles, aula de desenho, de xilo, de carpintaria, de teatro, de voz. Tinha um clima de arte; era como se você só pensasse em arte: música é que era importante, ballet é que era importante e as outras questões entravam como complemento daquelas. Vamos dizer: enquanto a escola tradicional coloca todo o saber intelectual como máxima e a parte do sentimento fica completamente jogado à deriva, na Waldorf eles juntam as duas coisas. A sensibilidade tem o mesmo valor que o pensamento, então, tua emoção e teu pensamento andam na mesma bandeja, juntos com a tua vontade. Eles trabalham muito a vontade de você executar o que pensou e o que sentiu. ${ }^{9}$

Voltei para o Brasil. Me lembro que fui direto para Pernambuco e Paraíba, para ficar com o Altino, que já estava morando lá. Passeei muito com ele por lá e vi o contraste: sair de Veneza

8 FERREIRA, Heloisa Pires. Entrevista concedida a Mayra Laudanna. Cotia: Ateliê Editorial, 2001. p. 24. (Entrevista de Artista).

9 Idem, ibidem. p. 25-27. 
referida (5). Tal sofrimento, sua "depressão", a artista o dramatiza com a hipérbole que contrasta o oficialismo da mudez e o florescimento da fala, de onde o mote da demanda: que os alunos e colegas nunca abram mão da fala e que, como a Professora, nunca desistam de insistir. A saída da depressão ou, o que é o mesmo, o nascimento para a fala, dá-se na narração dramática que tem por cena o Portugal da Revolução dos Cravos, onde Heloisa aprende, não sem dor, a liberdade (6). O contraste rebate-se, por isso, em outros pares de termos, não menos opositivos, como treva e luz, que o reinterpretam: para Heloisa, o silêncio é seu pretejamento pessoal e, ainda mais, o obscurecimento ditatorial, só sendo abolido quando se alteia, iluminado, o falante. É certo que, genericamente, o silêncio escurece tanto a fala quanto a arte, ainda que Heloisa declare ter trabalhado como artista apesar da mudez sofrida; embora tenha permanecido calada e sua arte não tenha desaparecido (7), esta não é tida, porém, como emancipada, estando a fala seqüestrada. Conseqüência disso é não só a demanda, assim, a fala ocuparem lugar central em Heloisa, pois, enquanto a maior parte dos artistas ou a alheia ou a instrumentaliza como se se tratasse de um acessório dispensável, ela a tem como constitutiva da arte. A fabulação educacional demonstra, assim, a eficácia da retórica na fala como política e terapêutica, não na pedagogia institucionalizada, mantenedora, como diz, do silêncio.

Do maravilhoso enquanto fala, a gravura e o bordado de Heloisa jogam com as espécies do contraste, como a contradição, a ambigüidade e o paradoxo, com os quais se produzem devires imprescritos, metamorfoses heterogêneas, correlações bizarras. Como ficcionais, a gravura e 0 bordado ora convergem ora divergem, e isso tanto no plano iconográfico, quanto no técnico e no retórico, nos quais se rebatem as operações. Os três planos expõem o que o binário forma-conteúdo, por sua indigência conceitual, não pode fazer, pois, nas gravuras, a figuração, com seus pássaros, sóis ou mapas, é iconograficamente a dos tecidos; tecnicamente, os procedimentos da gravura são homólogos aos dos panos; retoricamente, as fabulações na gravura e no bordado se correspondem, dramatizandose como maravilhosos seus rebatimentos nos três planos da ficção.

Tecnicamente, o bordado tem, com o suporte, relação distinta da que mantém a gravura com o papel na obra de Heloisa: enquanto na gravura as inscrições se produzem em um suporte homogêneo que com elas se modifica, no gerar mudanças cromáticas e luminosas com o bordado o suporte é evidenciado heterogêneo, feito de pedaços de tecidos, diferentes uns dos outros quanto ao fio, à tessitura e à estampagem que se ligam por meio de costuras com a aparência de bordados, os quais podem limitar-se aos recortes dos panos ou atravessar-lhes as bordas. $\mathrm{O}$ 
que visitei como bolsista e dar de cara com a pobreza do Brasil é uma coisa muito complicada. Aí, entrei em um outro tipo de cabeça, diferente daquela cabeça com que saí daqui. Eu saí daqui em depressão, já tinha acabado a depressão, que nunca mais voltou, e a coisa que veio era ligada com a questão social. Comecei a ver aquilo tudo que o papai me empurrava para ver desde que eu era pequena. Via, mesmo porque, de certa forma, estudei Marx: estudei com o Elias Cassibe, ele já morreu, ele também fez gravura, e com o Antônio Carlos Rocha, meu marido. Nós estudamos uns dois anos $O$ Capital, isso em 71, 72, [...] tudo escondido. ${ }^{10}$

5 Aos quinze, dezesseis anos, participava de um projeto com Maria Lúcia, Rogério, Luiz e Hugo Tomassini, mexendo com artes na favela de Santa Teresa. A gente fazia os chamados Domingos de Criação.

Até 1965, mantive esta atividade, mas o governo a proibiu. Na verdade, foi em 66 que veio a proibição de se continuar utilizando o espaço das favelas para questionar coisas. Então me desliguei. Não tive condições de continuar o trabalho, e fiquei muito deprimida. Rogério e Maria Lúcia foram morar na França - ela ficou uma temporada e ele ficou mais tempo - e eu passei a me dedicar à minha arte, num trabalho muito individual, individualista mesmo. Fui para São Paulo, trabalhei na escola antroposófica. ${ }^{11}$

6 Aquele ano foi fantástico e, apesar disso, eu tinha depressão: eu era uma deprimida ambulante... Aquele ano não, aquela década, aquela coisa preta, que só foi acabar quando fui embora para Portugal. Sabe quando começou a acabar? Cheguei a Lisboa, fui direto para um hotel e tinha de levar um pacote que a minha prima havia mandado para o Banco do Brasil. Um peso desgraçado; eu queria me livrar daquilo mesmo porque não fui

10 Idem, ibidem. p. 46-47.

11 FERREIRA, Heloisa Pires; LUZ, Maria Luiz (Coord.). Gravura brasileira hoje: depoimentos. Rio de Janeiro: Oficina de Gravura Sesc Tijuca, 1997. v. 3, p.40, 42. 
amarfanhado não opera nos panos, como nos doados pela artista ao IEB [Figs. 1 e 2], diferindo dos tapetes, que Heloisa ocasionalmente produz e nos quais o enrugamento do material é constitutivo da obra, pois com ele se modificam tanto suas cores quanto seu brilho.

Embora o bordado seja a arte com a qual Heloisa se inicia, é a gravura, mais que o desenho e a aquarela, que insiste em sua fala. $O$ devir dos bordados cruza o das gravuras, estando ambos associados a figuração comum, assim, seus pássaros, à diferença, decerto, dos supraaludidos tapetes, dispensados da figura. Heloisa supera, com isso, as restrições materiais que especificam cada arte, podendo propor-se uma estética geral para o conjunto de sua obra, na qual a cor, intensíssima porque saturada, opera como traço comum. Conquanto seu efeito se atenue na gravura, pois a incisão com traços curtos e justapostos de buril, correspondentes aos efeitos homólogos do bordado, não tem a intensidade cromática das linhas conduzidas pela agulha. O resultado técnico nas duas artes é a saturação cromática a ambas comum, no que a diferença intensiva pode ser atribuída apenas à matéria. Embora suportes, o papel e o tecido são ativos na produção da cor: o bordado e a gravura podem ser tidos equivalentes, considerada a saturação cromática em ambos operante [Fig. 3]. Materialmente, como o buril é o instrumento de Heloisa na produção de incisões curtas, seu uso corresponde ao trabalho da agulha nas linhas breves que se justapõem e, não raro, se sobrepõem em seu bordado, correlacionando-se, assim, não só os efeitos de saturação da matéria, como também os gestos e os instrumentos de que essa provém, o que reafirma a inclusão das duas artes em uma estética comum.

A ênfase dada ao buril não apaga outras técnicas de gravação em Heloisa; na calcogravura, a água-tinta opera efeitos pictorialistas, enquanto a xilogravura, ocasionalmente empregada com o metal, entremostra-se em efeitos análogos na variação produzida pela impressão da superfície da placa de madeira de fio. Nesses procedimentos, a arte do tecido está próxima da gravura, delimitando as áreas em que as linhas de bordado, como as de costura, definem as superfícies dos pedaços de panos que operam pictorialmente em seus limites. Outras correlações se estabelecem: os recortes das placas de cobre gravadas [Fig. 4] equivalem aos pedaços de panos recortados, uns aos outros fixados por costura; equivalem-se, também nesse cotejo, as reverberações produzidas graficamente pelas incisões do buril e as dos tecidos, sejam estes brilhantes, ou não. Constelação [Fig.5] exemplifica os traços que aproximam essas características da gravura às dos tecidos bordados: incisões e variações de superfícies na calcogravura e na xilogravura são homólogas às operações nos panos. $\mathrm{O}$ metal e a xilo expõem campo com miríades de figuras arredondadas que 
com a cara do hotel em que havia ficado. Fiquei insegura: "se isto some, essa minha prima me mata". Quando estou andando na rua - eles me explicaram como é que se chegava até lá a pé -, dei de cara com o maior painel do Partido Comunista. Isso não existia aqui, Partido Comunista, grandão, Comuna. Saí do Banco e entrei na tal Comuna, que era um lugar onde tinha livros, tudo o que você pudesse ler. Acho que a minha cabeça começou a rodar. E teve outra coisa: uns dias depois, fui conhecer o Museu das Janelas Verdes e me perdi. Já estava ficando escuro e comecei a ficar com medo: não conhecia direito o lugar, tinha saído daqui do Brasil, ditadura completa, onde você tinha medo até de olhar assim... Tinha um polícia ali, fiquei mais gelada do que nunca, mas era a única pessoa que tinha por ali para eu perguntar: "o que faço? Está ficando escuro, como é que vou voltar...”, cheguei para ele e falei: “meu senhor, pá-lá-lá", ele era de uma educação, de uma gentileza. Não tinha nem revólver! Só tinha cassetete, mais nada, eu reparei bem. Ele me ensinou até onde eu tinha de ir, me colocou dentro do ônibus que me deixou onde eu ia, todo educado. Aí, eu tirei um casaco de mim, um alívio: "você está num outro mundo, você está num mundo onde tem pessoas educadas". Aqui você fugia de qualquer polícia, não é? E ele viu logo que eu não era de lá, podia aprontar comigo... Nada, foi educadíssimo. Acho que a minha cabeça foi se abrindo, embora fosse inverno, tinha frio, tinha mil coisas de que eu podia não gostar, mas tinha um outro lado: eu estava completamente solta para olhar, para ver, para ler, para pesquisar, para isso, para aquilo, para ir a todas as Comunas, a todos aqueles festivais dos comunistas... A primeira coisa que li foram os volumes do Marx. Eu o tinha estudado aqui, no livro do papai. ${ }^{12}$

7 Nessa época, eu trabalhava muito. Como não dormia a noite inteira, tinha insônias eternas, não tinha para que dormir, eu passava a noite trabalhando. Dizia para mim mesma que vagabundo passa ao largo: "se você não quer dormir - não é que não quisesse dormir, não conseguia, um lado meu não queria dor-

12 FERREIRA, Heloisa Pires. Entrevista concedida a Mayra Laudanna. Cotia: Ateliê Editorial, 2001. p. 39-41. (Entrevista de Artista). 
se apegam ao fundo como se estivessem nele costuradas. $O$ gesto da incisão é, por sua vez, homólogo ao que costura pedaços de tecidos, também sendo homólogo aos movimentos da agulha que borda.

A homologia técnica entre gravura e bordado pressupõe a imanência de dois devires, o tornar-se gravura do bordado, o tornar-se bordado da gravura. $\mathrm{O}$ cruzamento dos dois devires reafirma a estética geral em que a arte de Heloisa se produz e, por desconsiderar precedências e hierarquias, nenhuma das duas artes se erige como modelo ou referência da outra; também, como alheia a normas, essa estética não unifica as artes sob princípios comuns, que as transcendam e, com isso, as reduzam a aplicações ou derivações. Viu-se acima que, tecnicamente, a gravura e o bordado se entre-explicam, o que situa o maravilhoso no cruzamento de ambos enquanto contrastados, sem referência à metamorfose, que neste plano não há. É admirável que, tecnicamente, o buril de Heloisa explicite a singularidade de seu bordado e, em troca, que este ponha em evidência a particularidade da ação daquele. A execução de uma arte com as características da outra sem reducionismo de parte a parte hiperboliza as duas, dramatizando-lhes os efeitos; o maravilhoso irrompe na saturação da matéria, tanto na gravura quanto no bordado, o que se atribui tecnicamente à repetição do gesto, buril ou agulha, intensificadora do procedimento específico de cada arte, que se hiperboliza.

Enquanto, no plano da técnica, os devires nas duas artes alheiam as metamorfoses por se restringirem discursivamente às coincidências e repetições, tudo se altera com a fala: o maravilhoso se amplia com a iconografia, cuja retórica se distingue da operante na técnica. É indicial que, nesta, o discurso de Heloisa se limite ao instrumental dos preceitos e, como a fala se caracteriza como ficção, no recorrente contraste entre os dois pólos o exterior ocupado pela matéria ou pela técnica ou pela obra, e o interior, tomado pela reflexão ou pelo afeto ou pela demanda, os termos contrapostos relacionam-se projetivamente como passagens de um dentro para um fora. Nessa articulação subjetivante, a fala, instância da interioridade, é envolvente como demandante e sentimental, encobrindo a arte e seu discurso do verossímil o halo fascinante da amplificação. Por isso, à diferença dos devires discursivos das gravuras feitas com buril e dos tecidos realizados com bordados que se entre-explicam em hialinos abismos de verossímeis, os falados disseminam as metamorfoses, que as homologias entre as técnicas desconhecem, restringindo-se à calcografia, hiperbolizada na fabulação. Duas retóricas, pois, se produzem, a do discurso operante na técnica e a da fala que, a essa reduzindo à condição de instrumento, envolve a iconografia. 
mir - já que você não quer dormir, você vai fazer coisas, você não vai ficar: 'a vida é uma tragédia... o mundo é uma tragédia... porque esse governo... e eu não posso falar', ou isso, aquilo, aquilo outro, 'porque aquele cara foi preso, o outro sumiu, o outro foi torturado..." " Você sabia tudo nas entrelinhas, "não: você vai trabalhar, você vai desenhar, você vai fazer gravura, você vai tentar pôr para fora tudo". Eu trabalhei tanto, tanto, tanto que acho que foi por isso que acabei ganhando a tal bolsa para ir a Portugal. Eu saí do Brasil em negra crise de depressão... só lá fui sair disso e nunca mais voltei. Depois, fiz o sofrimento da América Latina, quando já não tinha mais depressão; o que eu tinha era um sofrimento pelo sofrimento do nosso povo. [...] Está dentro de você a força; não vai ser o outro que vai te educar, vai ser você que vai se educar, você é que vai se lapidar, você é que vai se limpar e vai crescer e vai brilhar. Com o outro você vai ter um diálogo e vai crescer com ele, lógico, porque ele vai te alimentar... Não foi sozinha que eu cresci. ${ }^{13}$

8 Quando comecei pintando e desenhando - eu mexia com arte desde pequena e pintava muito e desenhava, não fazia gravura - tinha muito a questão dos pontos que eu fazia: dos pontos rebuscados, os detalhes de um ponto... Quando comecei a fazer gravura, era fruto dessas pinturas que não tenho mais. Essas gravuras eram como se fossem elétricos: tinham pontos e uma coisa de energia que ia girando para um outro ponto, era um ponto em relação a outro ponto... Quando comecei a fazer uns pássaros, não sei porque eu os comecei, eles sempre iam em direção a um ponto: uma claridade, um túnel... Havia alguns que estavam dentro de uma coisa. Cheguei a um ponto em que não fiquei mais interessada em fazer essas duas coisas juntas, pontos e pássaros: "agora eu quero pássaros numa e pontos na outra". Mas eu não poderia dizer que esses pontos das primeiras gravuras eram sóis: é como se os pássaros fossem para um lugar, para um todo, para uma claridade. Quando os separei, vi que os pontos existiam no espaço e, no espaço, eles viraram sol. ${ }^{14}$

13 Idem, ibidem. p. 17-18.

14. Idem, ibidem. p. 15-16. 
A demanda tem na fala, por seu apelo político e terapêutico, a evidência do ficcional. É neste plano, não no dos discursos da técnica, que a retórica se estende além da limitada às referidas repetições saturadoras, pois joga com a iconografia: ultrapassando as restrições da técnica, na qual domina a presença, a retórica opera com a ausência, constitutiva da descrição epidítica e do chamamento deliberativo, ligados não só à evidência e à moção, respectivamente, mas também aos devires enquanto seus focos. Pois, estes balizam as passagens entre o mostrado e o movido nos dois sentidos, no que a Heloisa protagonista se eleva como testemunha e como doadora. Como não se trata, nessa narração épica, da fala constituidora da subjetividade, mas da dos feitos em que triunfa a luz sobre a treva, expostos na ação dos personagens que desfilam no campo dos eventos gerados de contrastes e metamorfoses, os devires se enunciam fabulosamente. Mas, além da fala, que tudo envolve, há as gravuras e sua iconografia, no que a instrumentalidade da técnica contribui para fazer ressaltar a retórica, não, decerto, a restrita à saturação material, mas a que joga com os referidos focos. Essa retórica é a das passagens de um gênero a outro, presidindo a ambos a ausência, seja a epidítica seja a deliberativa, diferentemente da preceptiva do verossímil, em que a matéria é presença.

Envolvendo as gravuras em halo, a fala maravilha, assim, com a deliberação sobre a luz que deve vir e a treva a ser removida, mas também faz admirar tal ausência no deliberativo com a descrição epidítica do absconso. Louvadora na demanda da fala ou vituperadora na recusa do silêncio imposto pela ditadura do capital financeiro e seus quartéis, a gravura, na aura, embora não descreva, também evidencia; a similaridade do ente e do mapa em lances gráficos, como nos das coincidências de contornos, disseminações de signos, formas blasonadas, não anula o arbítrio na significação maravilhosa, não o suspendendo tampouco os tentames da etimologia. São as passagens entre o epidítico e o deliberativo que definem o plano retórico de Heloisa; como, entretanto, os gêneros não são por ela considerados, captam-se vestígios das operações a eles atribuídas em devires, metamorfoses e contrastes que evidenciam a fala no circuito das fabulações. Iconograficamente, é a fala que, velando o discurso procedimental da gráfica, faz nesta fabular, sem, contudo, anulá-la, pois a técnica remanesce como instrumento com a sua específica retórica material. Como a fala não suprime a técnica, mas a oculta enquanto presença ao discurso, a ausência, como constitutiva dos gêneros epidítico e deliberativo, é desencadeante do devir entre seus focos. Este trânsito é circular, implicando o fechamento dos devires sobre si mesmos; o gráfico é, por isso, retorizado como evidência e palavra 
9 Eu acho que essa coisa de expandir é o crescimento da gente que se reflete na arte, porque, quando me recolho, vou buscar os subsídios para falar e, na hora que vou falar, a coisa já está grande, até escapa de mim... Um papel de gravura, uma tela, um bordado são pedacinhos da nossa cabeça. Se fosse possível fotografar ou retratar o que passa na cabeça, não se tinha uma gravura ou duas, ter-se-ia milhares... mas não se pode pegar aquilo, não tem como! Eu tento figurar isso colocando em uma gravura pontos da sensibilidade desse mundo interior: na gravura, na pintura, no bordado, no desenho, na aquarela..$^{15}$

10 Essa época era muito tumultuada; isso antes dos mapas. Eu era muito angustiada, tinha muito sofrimento, tinha crises até de suicídio: não tinha razão de viver. Eu era muito complicada, mas, enfim... Fico vendo esses sóis e... "o quê será que havia naqueles poemas do Tiago de Melo?", porque eram poemas políticos. Ali ele falava da nossa situação - nós estávamos em plena época da ditadura, era 78, 77 - e, nessa época, em tudo que fiz coloquei essas diversas formas de sóis. Eu queria dizer com esses sóis que há luz dentro nós... há luz. Eu podia ser negra, como era, mas tinha que ter um outro lado.

Eu saí do Brasil em negra crise de depressão... só lá fui sair disso e nunca mais voltei.

Depois, fiz o sofrimento da América Latina, quando já não tinha mais depressão; o que eu tinha era um sofrimento pelo sofrimento do nosso povo. Eu era consciente de tudo o que passava, por isso chorava... [...] Nem sei quantos sóis eu fiz, foram saindo. Fiz um sol todo em buril, com um centro muito delicado, de muita sutileza: eu queria que fosse de muita sutileza o centro desse sol porque era como se fosse o centro de cada um, de cada ser humano, e ali é muito delicado. Dentro de cada um é onde tem a vida, onde vai brotar a esperança. É onde você vai criar, onde você vai inventar, onde você vai até poder ter forças para quebrar essa opressão de fora que te esmaga.

Essa história dos sóis, que eu acho que eles andam, eu diria que são três tipos de sóis: os sóis de 78 , de 79 , de 77 ; os sóis

15 Idem, ibidem. p. 10. 
de ordem, metamorfoseando-se a fala em cada foco. Veladas, a gráfica, como iconografia, e a retórica, como dois gêneros altos, explicitam-se na figura do dialogismo, pois a passagem de foco a foco não pressupõe primeiros e segundos, não havendo gravura que seja ilustração da fala, nem fala que dê a razão, também como instrumento, da gravura. É esse dialogismo que estabelece o processo que vincula a retórica, a técnica e a iconografia na fala de Heloisa.

Comandando a passagem entre os gêneros, a retórica de Heloisa avança uma iconografia alegórica do político, lugar outro da ausência sobre a qual se delibera e se descreve na fala épica cruzada pela significação gráfica. Sendo também alto o gênero da epopéia, tal alegorização traz, da fala, um outro caráter, cuja altura é a dos engendramentos, dos ortos, dos nascimentos: tratando-se da ausência, uma cosmogonia fabulosa reveza a política ficcional. A cosmogonia como a outra cena da ausência constitui-se com os devires e as metamorfoses de mil entes e mil classes, cuja heterogeneidade a semantização político-terapêutica torna homogênea. Da ausência, a gravura e a fala que a aureola nunca, contudo, se podem positivar, produzindo a inacessibilidade maravilhas na intersecção das operações projetadas nos três planos acima referidos.

A dimensão épica da personagem, não a cosmogônica dos elementos, distingue a memória, pois são mnêmicos os efeitos historiais em Heloisa, o que decorre da proeminência da interioridade como pólo radiante da narração. Em várias passagens, a artista categoriza a rede de seus argumentos com as noções recíprocas de interioridade e de exterioridade, projetivamente articuladas. Relacionando-se como espaços, interioridade e exterioridade configuram-se geometricamente como os pontos com o quais tudo se inicia, segundo a rememoração de Heloisa; nem na gravura nem no bordado, mas no desenho ou na pintura, de acordo com a sucessão temporal mnemicamente construída, os pontos surgem, embora, por inexistentes, as obras não possam confirmá-lo, ficando o leitor, quanto a essa assertiva, com a fala da artista. É nesta que o ponto, como hipérbole, explode; referência, faz ressaltar as amplificações: a numérica, na qual se dissemina, como nas nebulosas, a expansiva, na qual cresce como no sol, e a diminutiva, na qual se escancara, complexo, na evidência contraditória de pormenorizações e rebuscamentos. Labiríntico, o ponto devém, dividido, entre o infinitamente grande e o infinitamente pequeno, campo de metamorfoses no qual Heloisa diz, em paradoxo proliferante, sua ficção enleadora do contínuo e do discreto (8).

Os pontos tornam-se pássaros, sóis [Fig.6], nebulosas [Fig.7], pois labirínticos por se dividirem em si mesmos, apresentam-se como noções que interceptam o paradoxo e a contradição, afastando-se dos elementos 
de 83, dos quais um vai fazer a passagem entre esses mapas, porque já vinha a coisa do dinheiro, e um outro que não tem dinheiro, mas tem a estrela; tem ainda os que faço atualmente. Na verdade, nem sei se são sóis, acho que são muito mais cometas... são nebulosas, são coisas do espaço, mas são coisas do espaço meu, interno... ${ }^{16}$

11 Durante muitos anos, fiz, na pintura, centros de alguma coisa, como se fossem labirintos indo dar em algum ponto. Verdadeira contradição, labirinto e centro, não? Eu não conseguia entender muito porque tinha que fazer essas coisas. De repente, começaram a surgir figuras humanas, sempre ligadas a algum centro. Os labirintos desapareceram, surgiram no lugar deles as figuras em busca de um centro e depois começaram a vir os bichos que iam para algum centro também. Eram uns pavões bem elegantes e todos cheios de penugem. Trabalhei esses pássaros em desenho, pintura, gravura e tecido. Eram pássaros imensos, todos cheios. Sempre havia centros em volta e esses centros se tornaram centros mesmo. Depois, eles se tornaram sóis e luas. Eu tinha gravuras chamadas Sol Negro, Sol Vermelho, Sol Amarelo. E começaram a desaparecer as texturas rendadas dos bichos. Os bichos começaram a ficar quase sem plumagens e as plumagens se transferiram para galhos que surgiam interferindo com os bichos. Esses bichos continuaram, desapareceram todos os galhos, ficaram sozinhos e ficaram os sóis sozinhos. Comecei a trabalhar nos sóis que apareceram em céus. Eu vou penetrando nas coisas e vai acontecendo a transformação.

Esses sóis se expandiram no espaço. ${ }^{17}$

12 Tenho uma gravura que é um dragão: “México". É um dragão, a cara do dragão, o rabo do dragão, mas esse dragão, no desenho, não era dragão. Sempre faço o desenho no papel vegetal,

16 Idem, ibidem. p. 16-19.

17 FERREIRA, Heloisa Pires; LUZ, Maria Luiz (Coord.). Gravura brasileira hoje: depoimentos. Rio de Janeiro: Oficina de Gravura Sesc Tijuca, 1997. v. 3, 123-124. 
da geometria euclidiana. Esses elementos ou, como lhes chama a artista, "pedaços interiores", são, como se referiu, por ela qualificados de rebuscados, detalhados, expandidos. Por ignorarem o paradoxo e a contradição no plano gráfico, tais pontos lançam em seus labirintos a maravilha como fabulação da fala, atribuída unicamente à interioridade, uma vez que não podem ser "pegos ou fotografados", como diz a artista (9). Noção elementar da fala, o ponto, como historial, inscreve-se retoricamente no gênero alto, não no domínio da deliberação, mas no da demonstração. É por isso que Heloisa o determina de muitos modos, podendo ressaltar-se, metaforicamente, o gravitacional, que, na proposição do campo elétrico, atrai outros seres com os quais devém, estabelece contrastes e opera metamorfoses. Mais, porém, do que física, a energia do ponto, no atrair seres, metamorfoseia-se em túnel e luz [Fig.8], epidítica maravilha, pois, também, quando se expande, faz surgir sóis, os quais, por sua vez, se disseminam e, pletora de pontos, tornam-se nebulosa, como se viu (10). Mas o devir não afeta somente o ponto, pois também os seres atraídos sofrem metamorfoses, como os pássaros, que, quando em relação a ele autônomos, tornam-se montanhas, árvores, fantasmas (11). Assim, nos devires, as metamorfoses são irredutíveis à homogeneidade e à linearidade; considere-se o devir recíproco entre pássaro e árvore [Fig.9], um se metamorfoseando no outro: nesta fala, há visionarizador porque o olho não se instala na comodidade da hierarquia visual em que um termo é o que devém e o outro, o que deveio.

Há, também, devires de afetos, como nos mapas, em que as metamorfoses seguem ora a linha da dor, ora a do júbilo: obra da gráfica, tanto da que, tecnicamente, faz preponderar o buril quanto da que torna proeminente a água-tinta, nas quais a similaridade da forma dialoga com a hipérbole da fala, cortada pela política. Nesses devires, Heloisa fala sobre seu luto e sua esperança no concernente à América Latina; enquanto os primeiros mapas são de dor, como no da Argentina [Fig.10 - Pedaço da América], pintalgada dentro e fora das fronteiras por signos que a artista qualifica de caveiras, nos ulteriores é o júbilo que explode, como no mapa do México, no qual o desenho cartográfico se metamorfoseia em desenho animalista, iluminando-se como alegoria de renascimento a metamorfose do mapa em dragão (12). A partir da cartografia animalista do México, segue-se a figuração dos Estados do Brasil que proclama, também ela, afetos afirmativos nas metamorfoses amorosas de bichos, de que o Estado de São Paulo [Fig.11] é bom objeto.

Recebido em 15 de março de 2008

Aprovado em 11 de julho de 2008 
não desenho um projeto de gravura arrumadinho e escrevo ao lado dele todo o resto que vier à minha cabeça. Eu sabia que em alguns mapas tinha que colocar a roda dos ventos, as siglas dos países, o dinheiro no centro de algumas roda dos ventos, que era o que estava girando... Fiz o "México" como uma carta antiga: antigamente os mapas tinham essas marcações que pus nele. Nos mapas muito antigos o mundo não era redondo, era plano, no caso, o "México" é plano... Em nenhum mapa que faço, a figura fica como está na carta: sempre que você olha o Brasil a parte fina está embaixo. A minha visão não era assim, de nenhum país da América Latina, porque, na verdade, não tem um lado para você olhar. O lado que eu tinha para olhar antes, que eu nem olhava, era aquele Brasil ali, e eu nem sabia o que acontecia no resto do continente. Depois que estudei isso, fui mudando tudo: virei, então, aquela figura do México e passeei com ela até que me aparecesse um dragão.

Nos outros, tinha muito a coisa da caveira: tinha a caveira da Argentina, porque eu também estava chorando a morte dela. Eu via a cultura morrendo, o amor morrendo, o respeito humano morrendo, porque só o dinheiro valia. O que vale é uma meia dúzia de fulanos que têm não sei quantas casas, que não sei para que servem, não sei quantos carros, que não sei para que servem, e não sei quantos empregados, que não sei para que servem.... Na verdade, quando se deita numa cama para dormir, deita-se em uma cama, não é preciso ter oitenta camas. Inclusive atrapalha! Atrapalha o teu centro de energia. Eu via que muitos dessa América Latina inteira não têm cama: dormem no chão, na terra, debaixo da marquise, sei lá onde dormem.

Quando cheguei ao "México", ele virou um dragão; falando hoje, vejo que o dragão é um mito que resgata: é como se, de repente, ele começasse a dar vida aos outros países. Eu já tinha a esperança de que as coisas não só morressem, mas que elas também pudessem renascer, como o dragão das cinzas. Então, essa cultura podia voltar, não sei como, mas podia voltar pelo menos dentro da minha esperança, e foi ali que se abriu o caminho para as gravuras que vieram depois. ${ }^{18}$

18 FERREIRA, Heloisa Pires. Entrevista concedida a Mayra Laudanna. Cotia: Ateliê Editorial, 2001. p. 12-14. (Entrevista de Artista). 


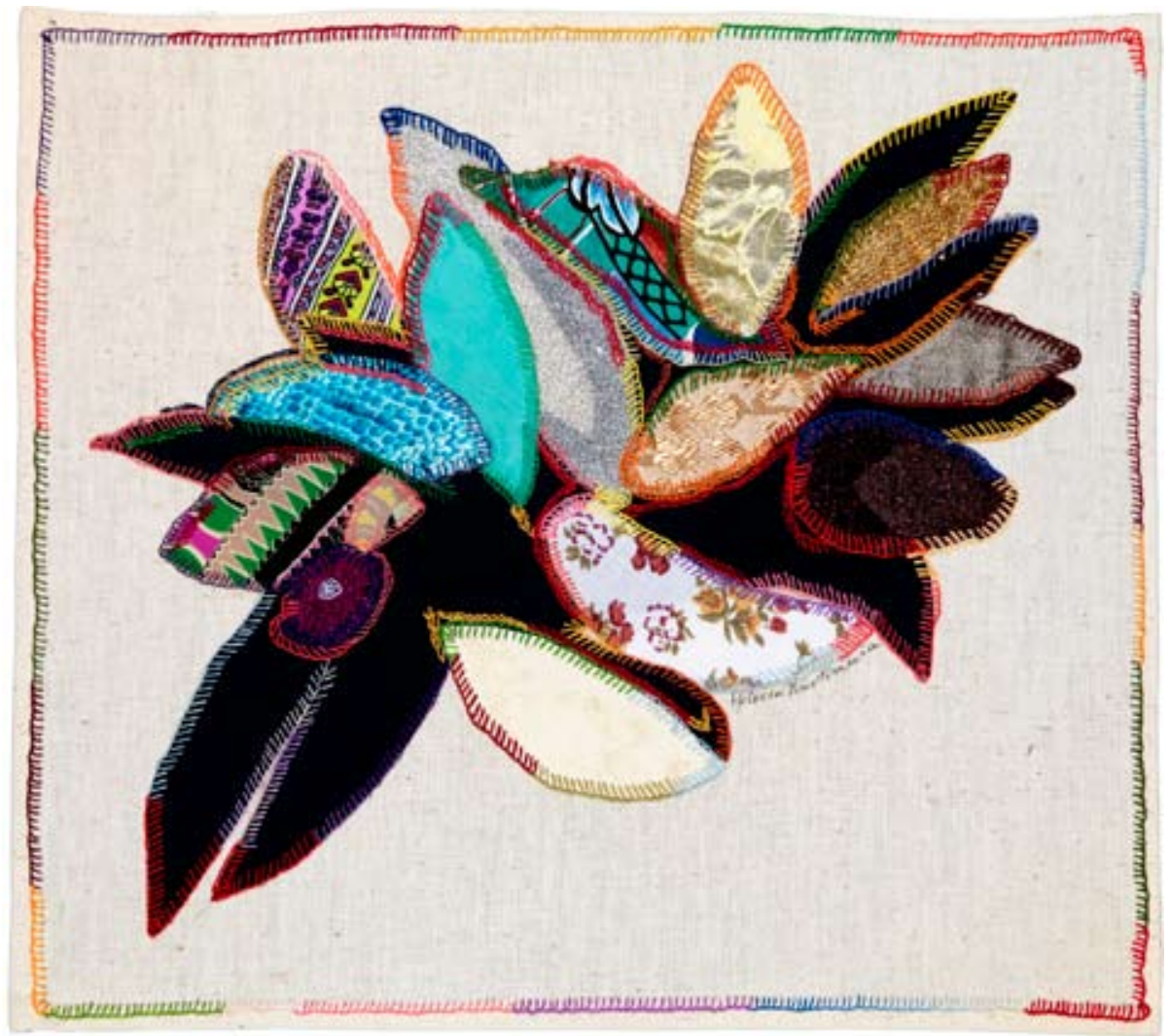




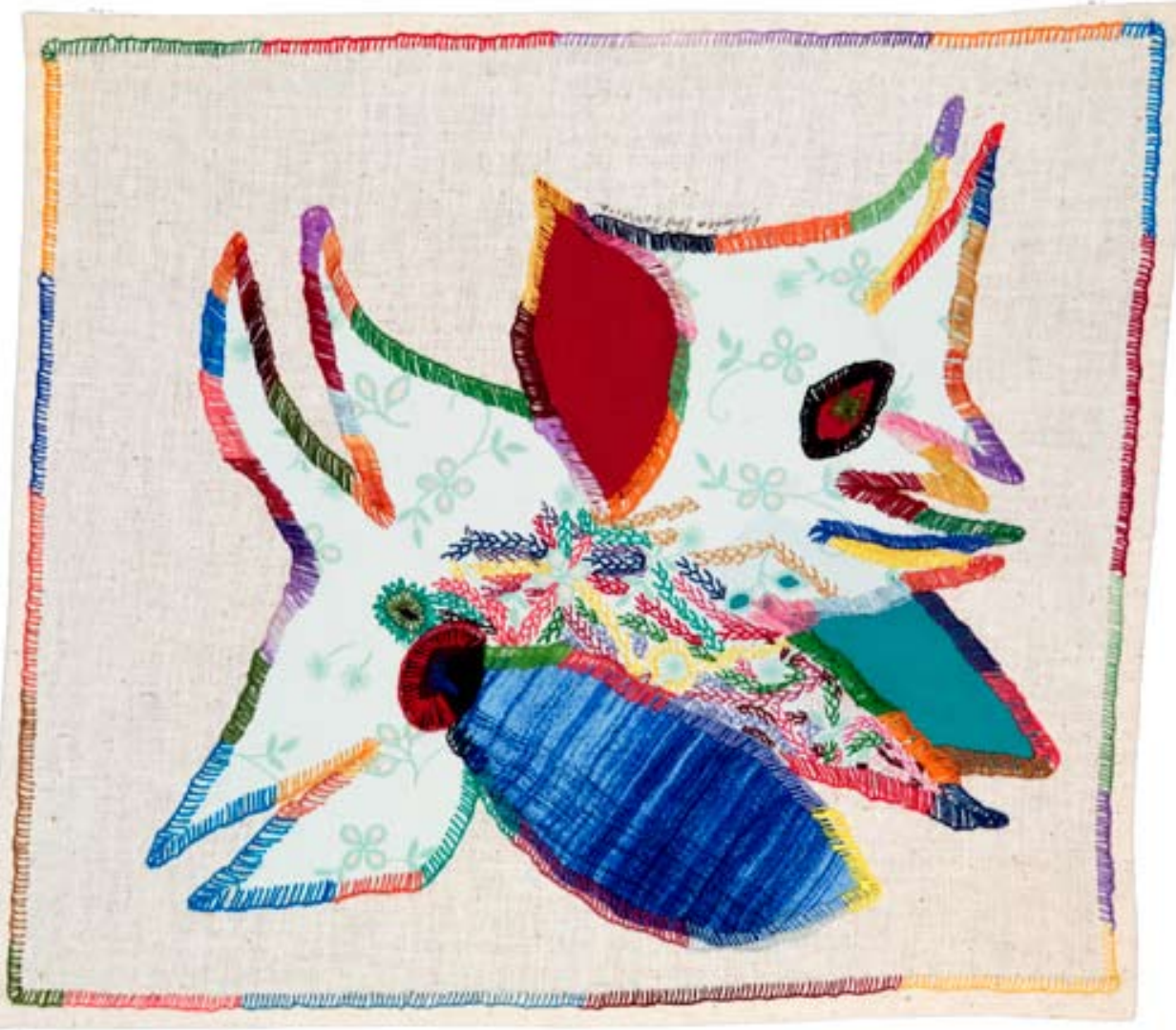




\section{Sem título}

FERREIRA, Heloísa Pires água-forte, s.d.

$29,5 \times 29,8 \mathrm{~cm}$

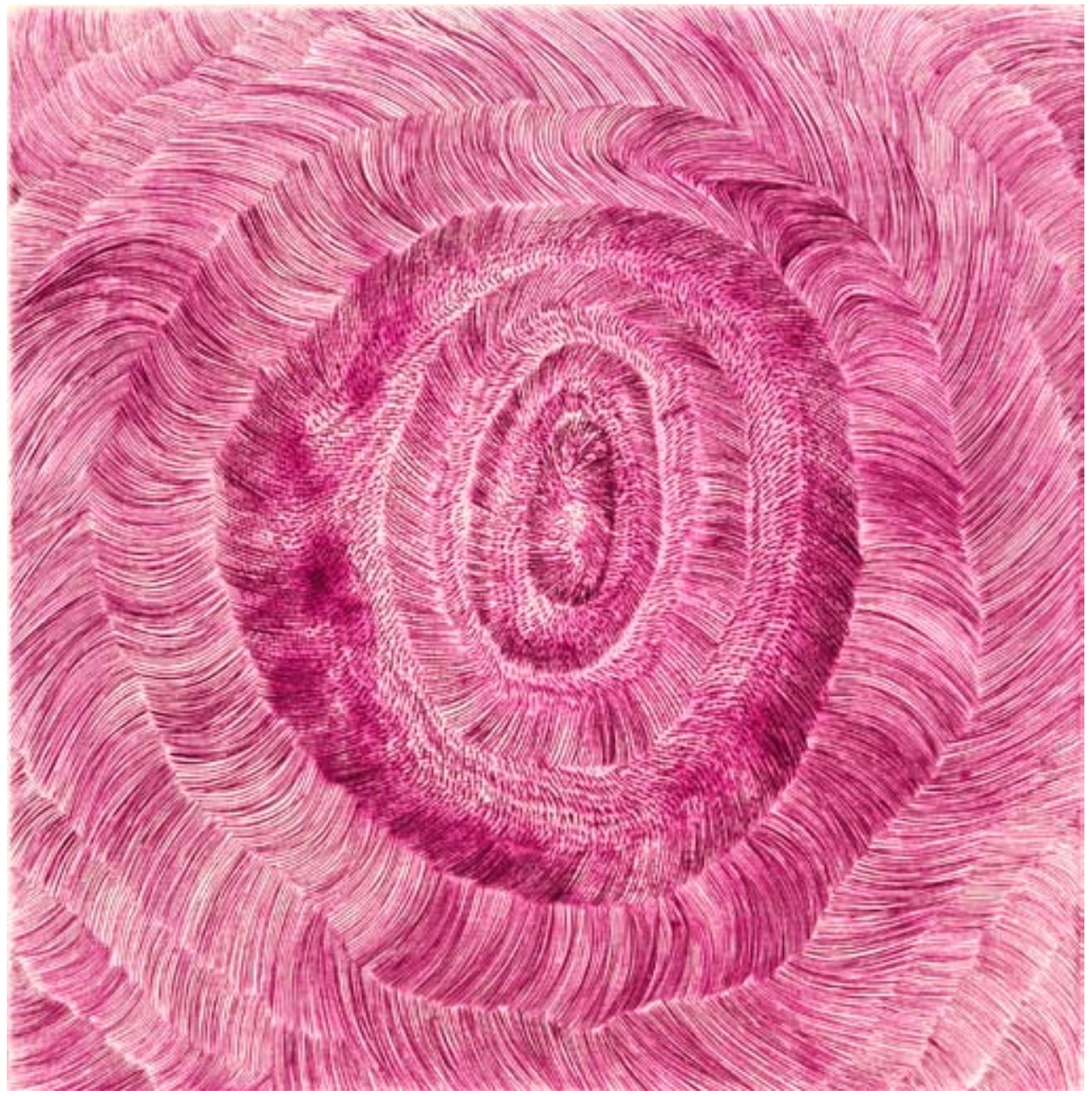




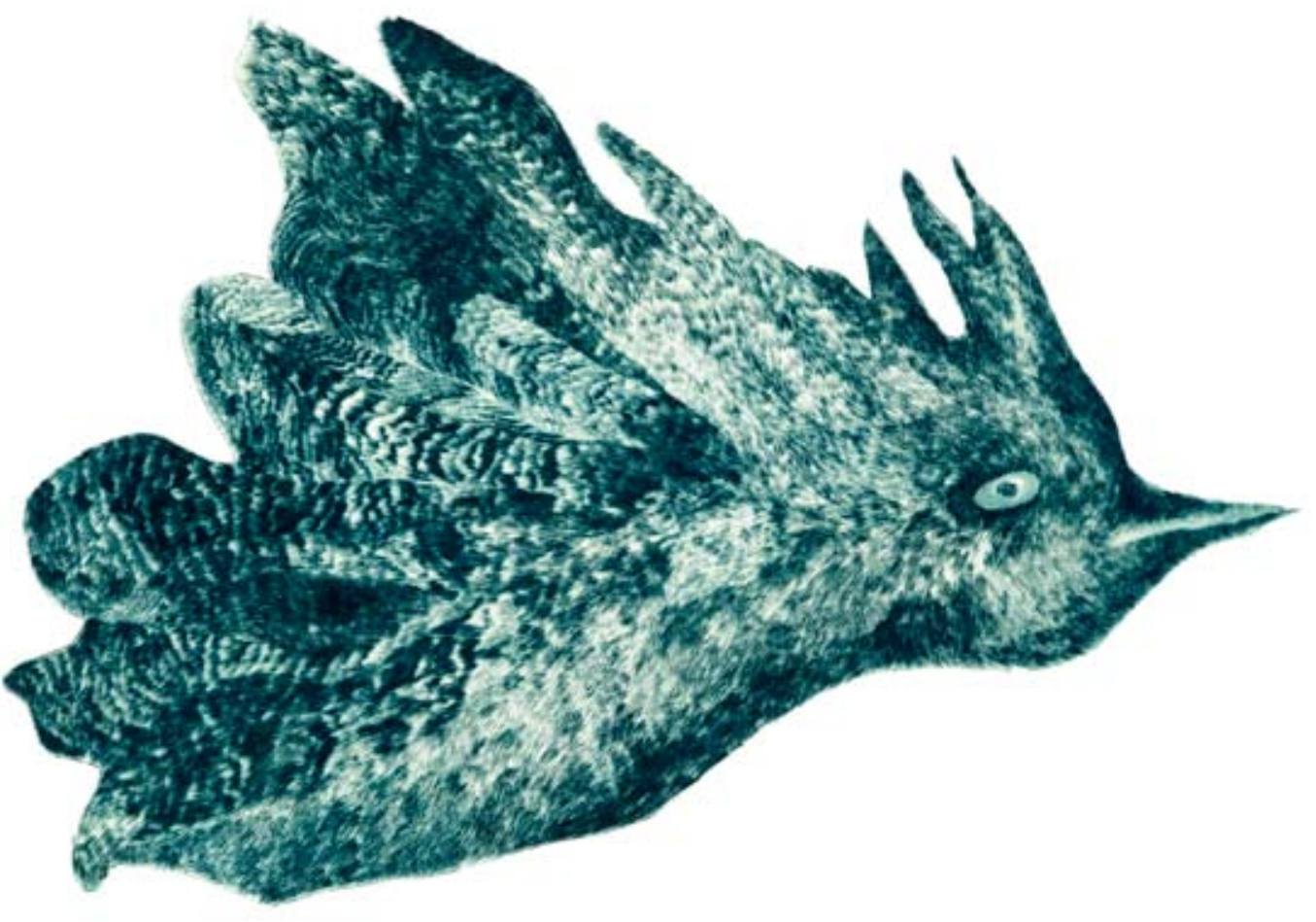




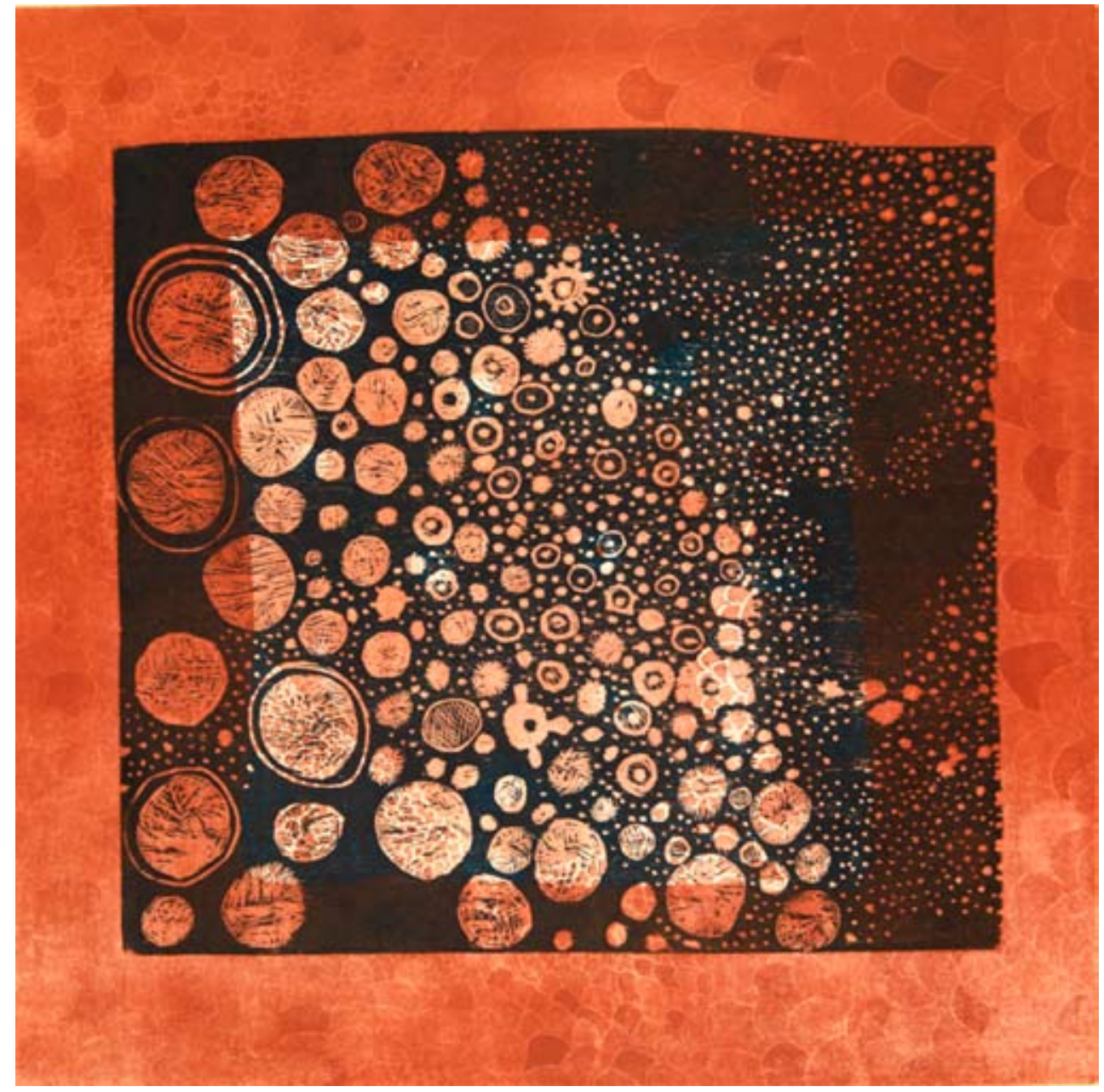




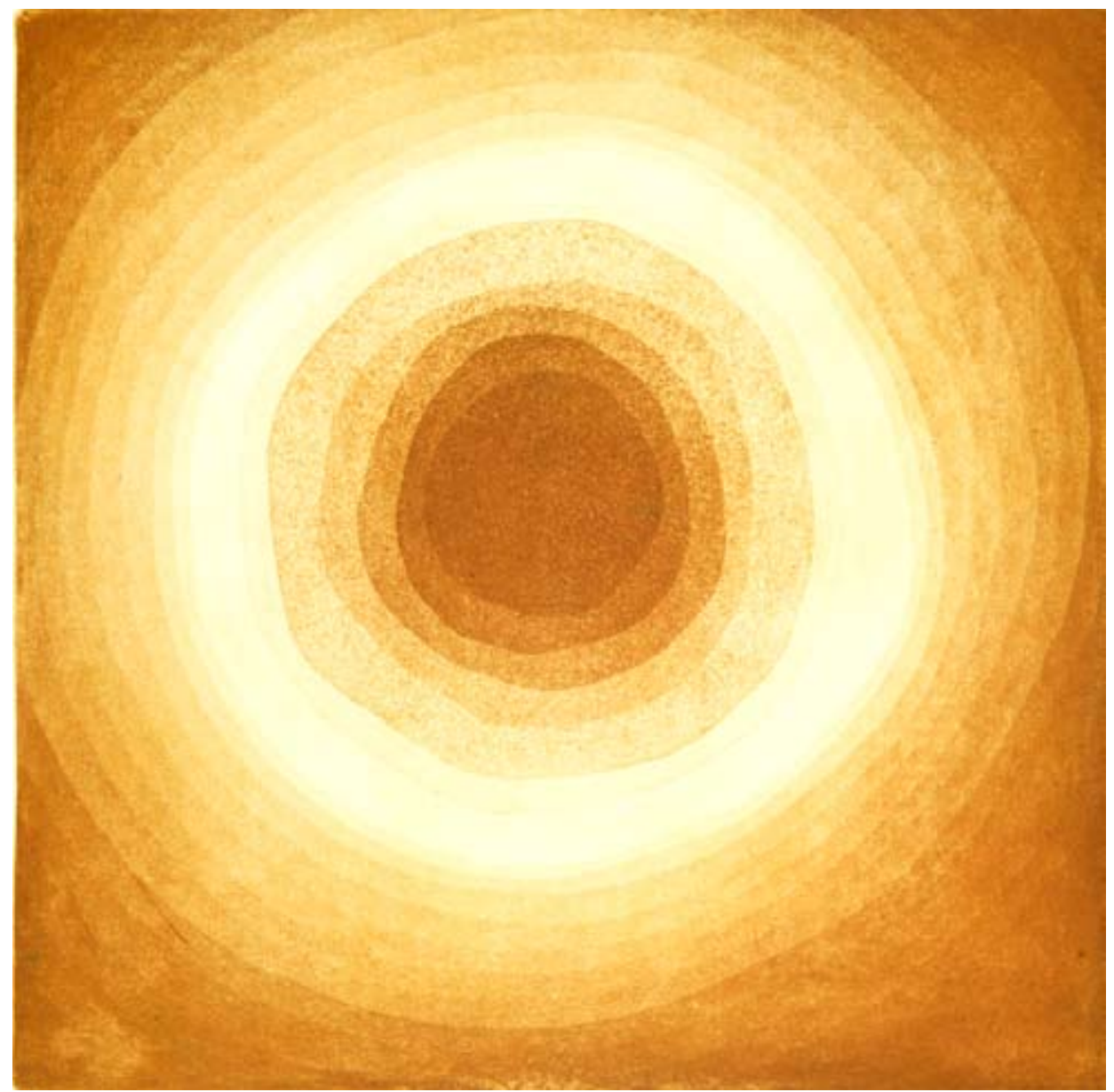

Sem título

FERREIRA, Heloísa Pires água-tinta sobre papel, s.d. $39,2 \times 39,5 \mathrm{~cm}$ 


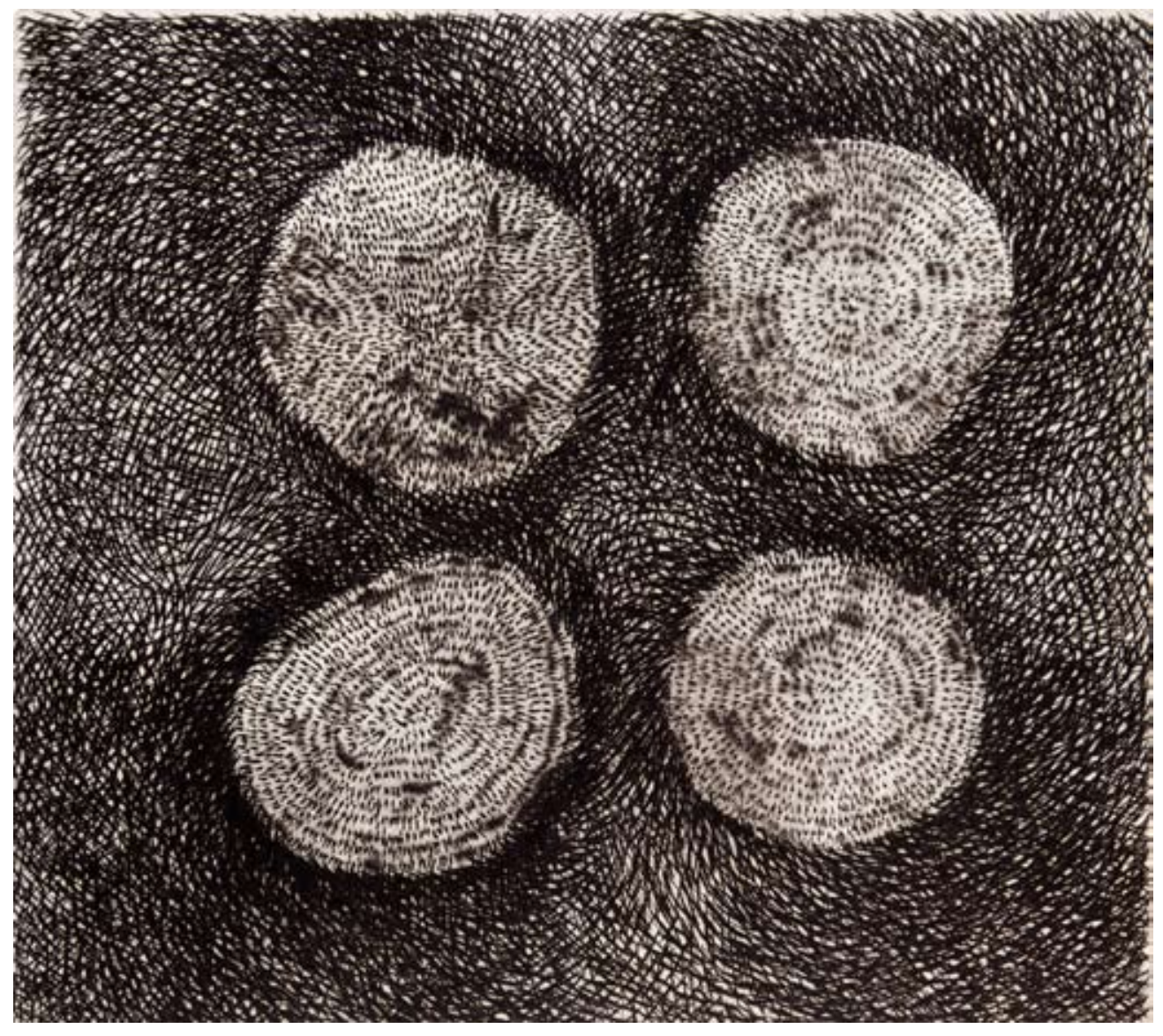


Sem título

FERREIRA, Heloísa Pires

água-tinta colorida, s.d.

$39 \times 59,2 \mathrm{~cm}$

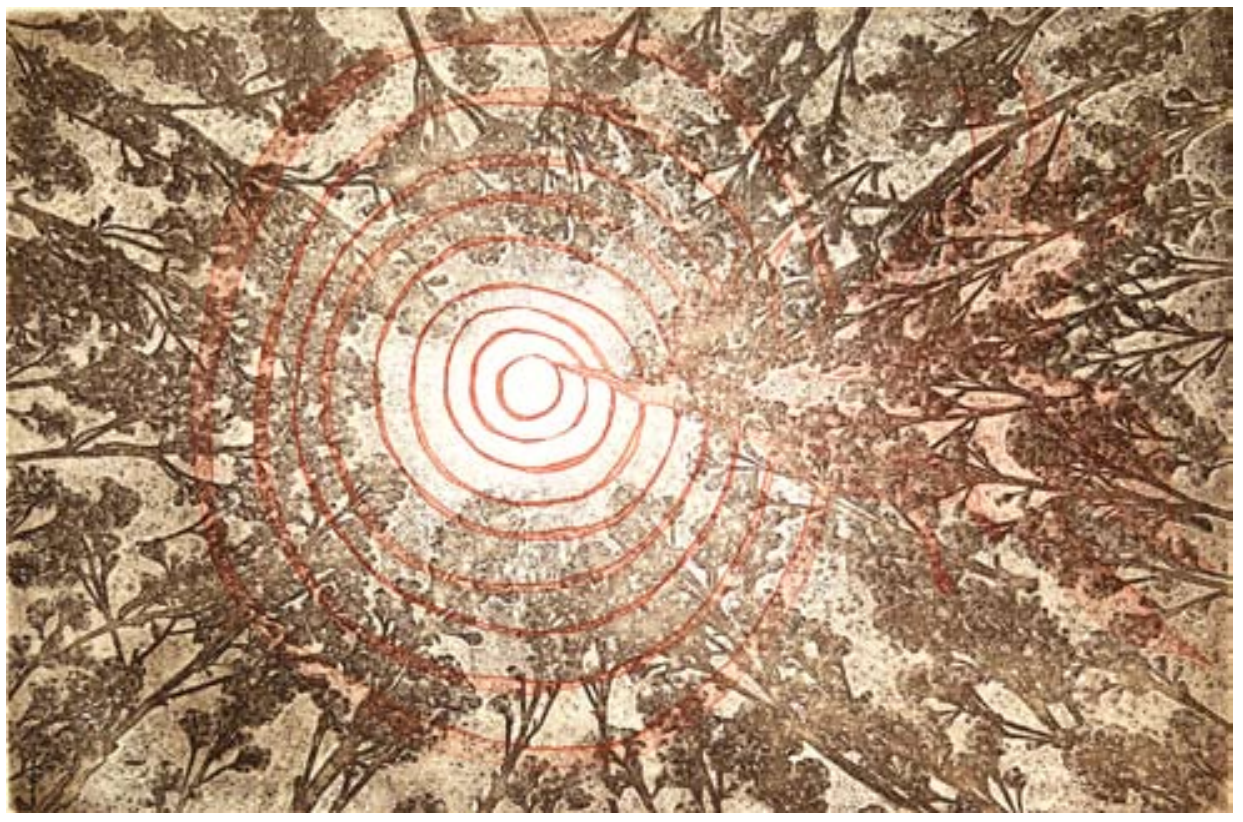


Sem título

FERREIRA, Heloísa Pires

água-forte e ponta-seca, s.d.

$66 \times 41,5 \mathrm{~cm}$

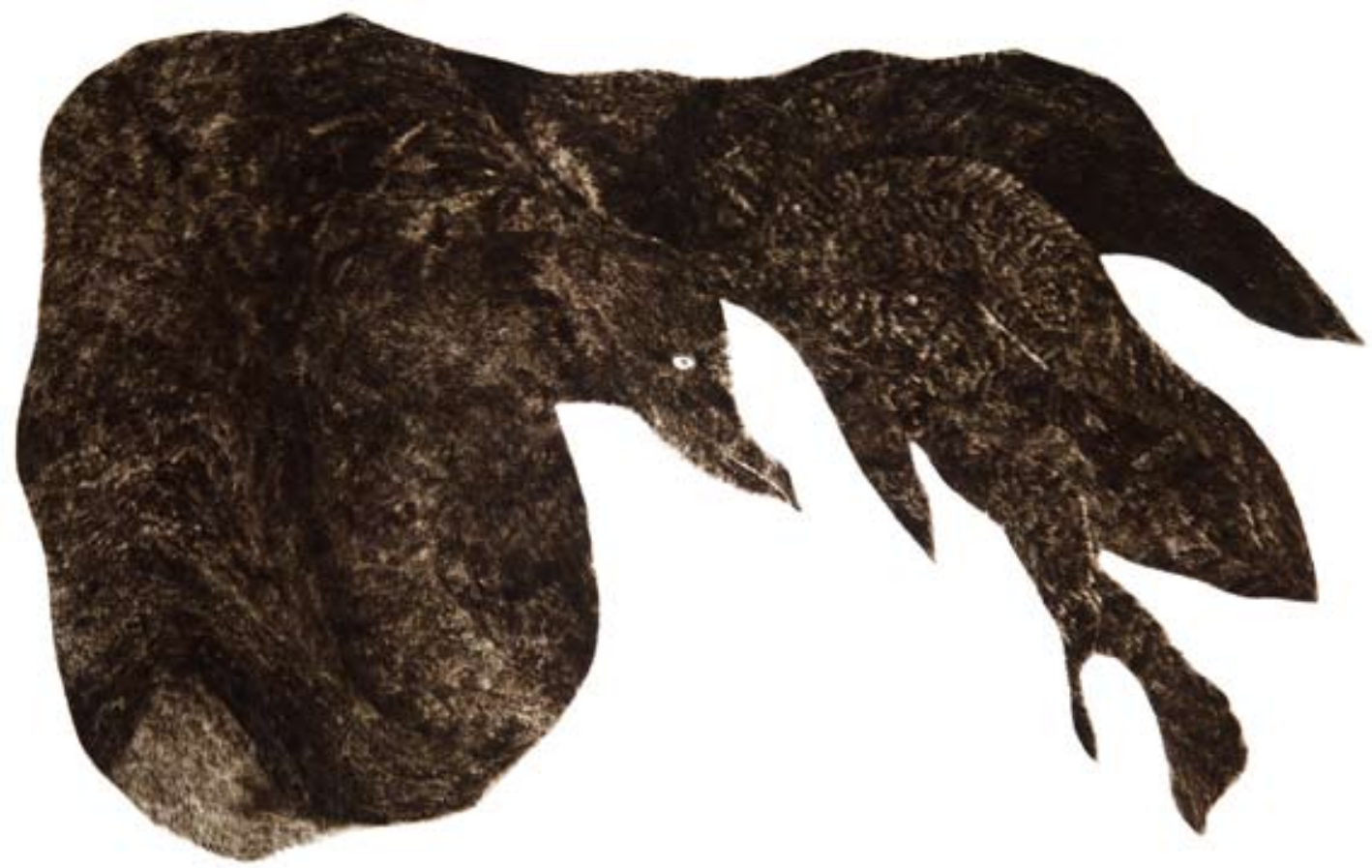




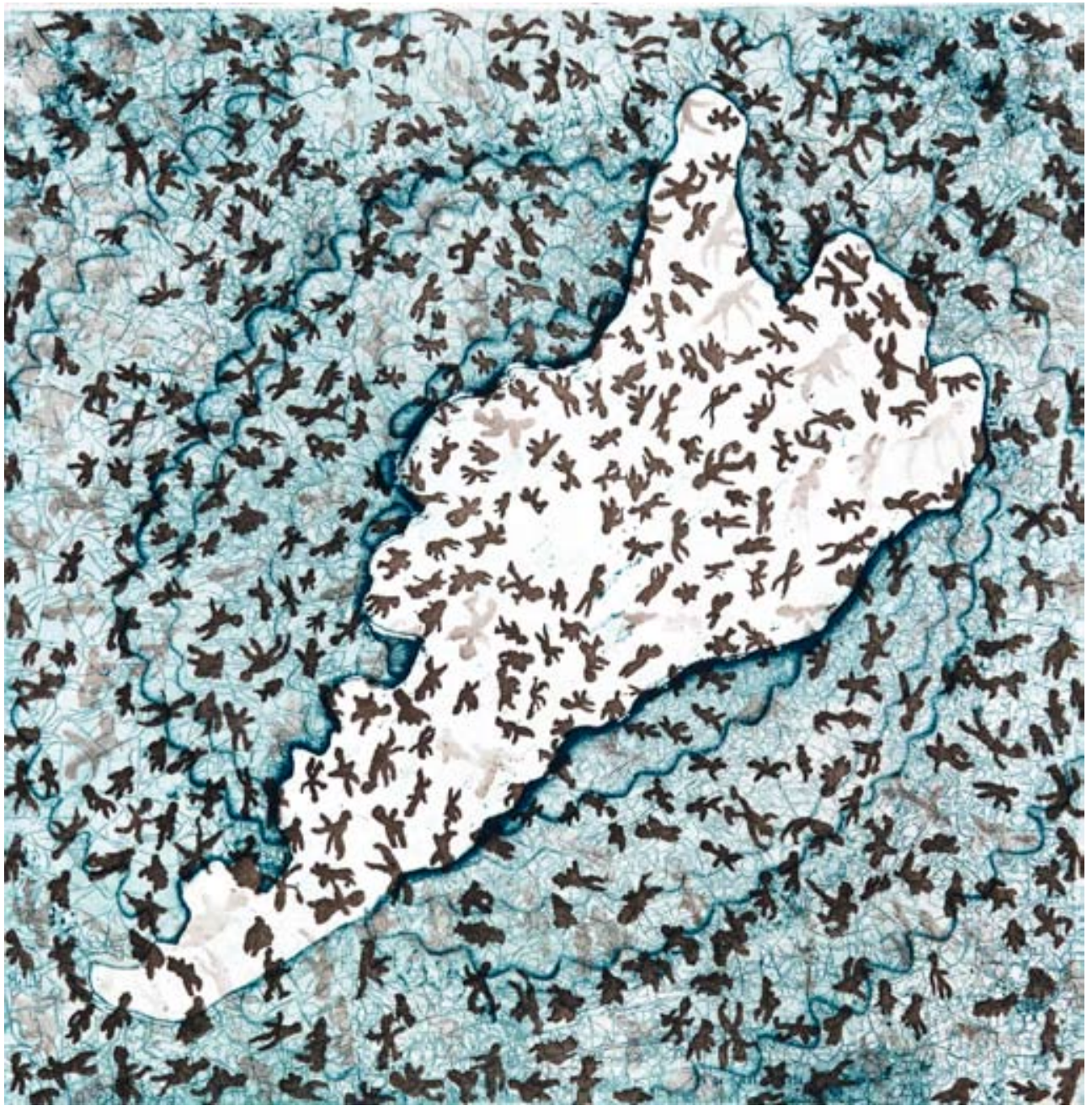

Pedaço de América

FERREIRA, Heloísa Pires água-forte e água-tinta colorida, s.d. $29,9 \times 29,5 \mathrm{~cm}$ 


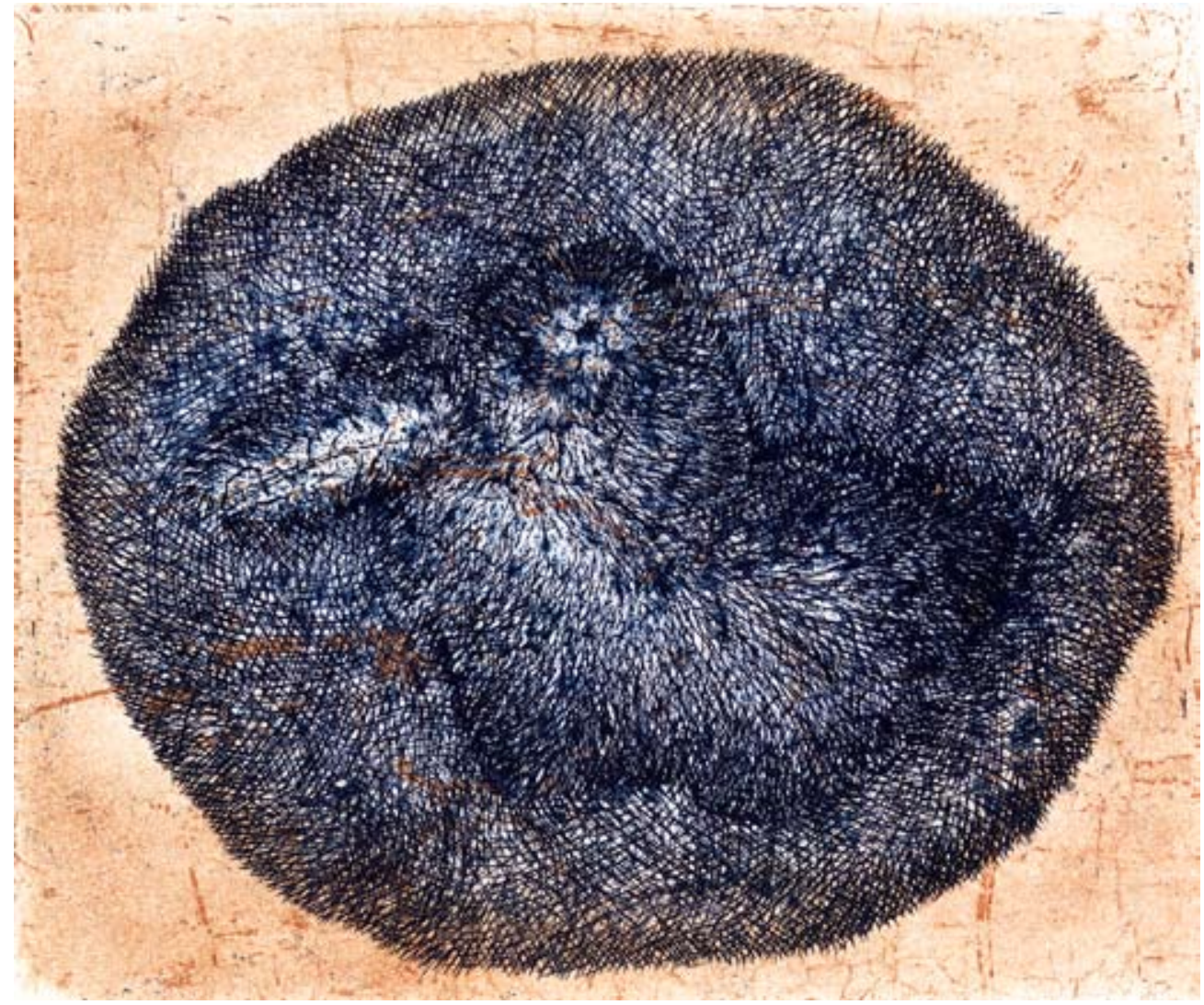

São Paulo

FERREIRA, Heloísa Pires água-forte e água-tinta colorida, s.d. $20,5 \times 24,1 \mathrm{~cm}$ 